\title{
The Impact of Translation Techniques on the Quality of Translation of Judgment Expression that Describes the Main Characters in the Untamed TV Series
}

\author{
Adilla Achmad Syahputri ${ }^{1}$; M R Nababan ${ }^{2}$; Tri Wiratno ${ }^{2}$ \\ ${ }^{1}$ Postgraduate Student, Linguistic Program, Universitas Sebelas Maret, Surakarta, Indonesia \\ ${ }^{2}$ Professor, Linguistic Program, Universitas Sebelas Maret, Surakarta, Indonesia \\ http://dx.doi.org/10.18415/ijmmu.v8i9.3046
}

\begin{abstract}
The translation technique used in translating subtitles greatly affects the quality of the resulting translation, both in terms of accuracy, acceptability, and readability. This study aims to determine the impact of choosing a translation technique on the quality of the translation and the impact of shifts that occur due to the selection of an inappropriate technique. Since this study focused on Judgment's expression which describes the main character, this study is categorized as a descriptive qualitative study that focuses on translation research. Data were collected from focus group discussion analysis content. This study found that there were 5 types of judgment expressions with a total of 194 data. The type of judgment that was most often used to describe the main character is propriety. There were 8 techniques used in this translation and the techniques that most affect the accuracy of the translation are deletion and discursive creation. The results of the focus group discussion also show that although it was found that 41 data experienced a shift, the quality of the translation in terms of accuracy, acceptability, and readability had a good score.
\end{abstract}

Keywords: Subtitle; Translation Quality; Translation Technique; Judgment Expression; Translation Shift

\section{Introduction}

Unlimited information exchange makes everyone consciously or unconsciously carry out the process or enjoyed the translated product. Starting from translated books, songs, games, even films from abroad are also translation products. One of the translation products that is always encountered when enjoying foreign films, especially from streaming platforms, is subtitles. The existence of subtitles as a bridge for non-first language speakers has a very important role to properly convey the message. Since the existence of subtitles is important, the quality of the translation has a holistic quality. Nababan (2012:44) explains that a quality translation is required to meet three aspects, namely accuracy, acceptability, and legibility.

Furthermore, looking at the translation side, a linguistic approach is also needed to produce a quality translation. One approach that can be used is Systemic Linguistic Functional (SFL). SFL views language as a social phenomenon that is reflected in its use. Besides, SFL divides the language function called meta- 
functional meaning into three language functions, namely ideational, interpersonal, and textual. In the interpersonal sense, there is an appraisal system that can be used as an approach in translation.

The interpersonal function in SFL expresses the social relationship between the writer or speaker and the reader or listener, further developed and explained in the Appraisal system. Martin \& Rose (2007:26) explain that Appraisal is a system in interpersonal meaning that is used to negotiate social relationships, by explaining to the reader or listener the assessment of objects or people (attitude). Attitude in the appraisal system is further divided into three types, namely affect, judgment, and appreciation. Of the three types of attitudes, Martin \& White (2005) revealed that judgment discusses behavior - how a person behaves and if he deviates, he will be punished both socially and legally.

There have been several studies on translation that use System Appraisal as the approach, such as studies conducted by Sutrisno (2013) and Iswandi (2019). In both studies examined the translation of attitudes about the main character in the novel. Meanwhile, a study conducted by Aji (2017) examined the expression Judgment found in two translations, while a study conducted by Zhaoying examined the attitude contained in the film's subtitles. These studies examined the techniques used in an expression containing the Appraisal system and look at their impact on translation quality.

Although there have been several translation studies using Appraisal, there are still few who study films, especially those from streaming platforms as research data. Furthermore, as far as the researchers are concerned, there has been no research on the quality of film translation using the Appraisal approach, especially from Mandarin to Indonesian. Therefore, the data of this study was limited to Judgment's expression about the main character in the Mandarin film that is on the streaming platform. The selection of The Untamed TV Series as a data source for the depiction of the main character who was initially considered a hero by everyone but turned into everyone's enemy. How the translator describes the Judgment expression in the translation must be based on the social context that arises when the expression is uttered since Nababan et al believe that the Appraisal discusses describing the form of language according to its social context, which is following the principle of quality translation. Moreover, both the structure of the language and culture of Indonesian - Mandarin are different, making the researchers are interested in conducting this study.

\section{Research Methods}

This study is translation research employing a qualitative descriptive approach since the researchers understand the real phenomena that occur in the data and described them. The data included in this study were Judgment expressions in The Untamed TV series and their translations. The data were selected based on the theory of Appraisal by Martin and Rose (2007). The data were validated by questionnaires and focus group discussions (FGD) before being analyzed. The translation technique used was the classification of translation techniques from Molina \& Albir (2002). Meanwhile, the quality of the translation was analyzed using the theory of Nababan, Nuraini, and Sumardiono (2012). Furthermore, the data were analyzed through domains, taxonomies, and components to show the analysis of cultural themes (Santosa, 2017).

\section{Results and Discussion}

\subsection{Judgment Expressions}

Martin \& Rose (2007:68) suggest that in the Appraisal system, judgment is divided into two assessments, namely social esteem, which is social recognition related to personal evaluation and social witnesses, and social sanctions related to moral evaluation if violated, they will get punishment either by custom as well as law. Judgment assessment can be in the form of direct or indirect sentences. It can also be positive and negative. In social esteem, positive sentences are called admiration, while those that are negative are called criticizing. In social witness assessment, those that are positive are called praise, while those that are negative are called condemnation. 
Table 3.1 Types of Judgment

\begin{tabular}{|c|c|c|c|}
\hline \multicolumn{2}{|c|}{ Jenis Judgment } & F & Percentages \% \\
\hline \multirow{4}{*}{ Positive } & Normality & 29 & 14.95 \\
\cline { 2 - 4 } & Capacity & 22 & 11.34 \\
\cline { 2 - 4 } & Tenacity & 16 & 8.25 \\
\cline { 2 - 4 } & Veracity & 2 & 1.03 \\
\cline { 2 - 4 } & Propriety & 9 & 4.64 \\
\hline \multirow{4}{*}{ Negative } & Normality & 38 & 19.59 \\
\cline { 2 - 4 } & Capacity & 2 & 1.03 \\
\cline { 2 - 4 } & Tenacity & 1 & 0.52 \\
\cline { 2 - 4 } & Veracity & 8 & 4.12 \\
\cline { 2 - 4 } & Propriety & 67 & 34.54 \\
\hline
\end{tabular}

The table above presents that the type of judgment that is often used to assess the main character. From 194 data, the types of judgement found were propriety (-) of $34.54 \%$, normality (-) of $19.58 \%$, normality (+) of $14.59 \%$, capacity (+) of $11.34 \%$, tenacity (+) of $8.25 \%$, propriety (-) of $4.64 \%$, and veracity $(-)$ of $4.12 \%$. Furthermore, there were capacity (-) and veracity $(+)$ which have the same percentage of $1.03 \%$. Meanwhile, the least type of judgment in describing the main character was tenacity (-) of $0.52 \%$.

Those data indicate that in describing the main character, the writers used expressions that contain judgment (assessment of the character and behavior) for $60.31 \%$ of the data describe the character of Wei Wuxian negatively. Meanwhile, $39.69 \%$ of the data described the main character positively. The depiction of the main character dominated by negative expression requires carefulness by the translator. Thus, the intent to be conveyed by the writers can be conveyed to the reader properly. This can be fulfilled if the translation results have a holistic quality.

\subsection{Judgment Expression Translation Techniques}

As explained above, there were 10 types of judgment expressions used in evaluating or assessing the behavior of the main character. In translating these expressions, different translation techniques are needed in order to produce quality translations. The translation techniques used by translators found by researchers are described in the table below.

Table 3.2 Translation Techniques in Judgment Expressions

\begin{tabular}{|c|c|c|c|c|c|c|c|c|c|c|c|c|c|c|c|}
\hline \multirow{2}{*}{ No } & \multirow{2}{*}{\multicolumn{2}{|c|}{ Judgment }} & \multicolumn{12}{|c|}{ Translation Techniques } & \multirow{3}{*}{$\begin{array}{r}\text { Tota } \\
29\end{array}$} \\
\hline & & & $\mathrm{EE}$ & $\mathrm{Tr}$ & DC & Im & Mod & Ex & Del & $\mathrm{Re}+\mathrm{Tr}$ & $\mathrm{Re}+\mathrm{EE}$ & $\mathrm{EE}+\mathrm{DC}$ & $E x+E E$ & $\mathrm{~Pa}$ & \\
\hline 1 & \begin{tabular}{|l|} 
Positive \\
\end{tabular} & Normality & 22 & & 1 & 1 & & & & 1 & 3 & 1 & & & \\
\hline 2 & & Capacity & 15 & & 3 & & 1 & & & & 1 & 2 & & & 22 \\
\hline 3 & & Tenacity & 12 & & 1 & & & 3 & & & & & & & 16 \\
\hline 4 & & Veracity & 1 & & & & 1 & & & & & & & & 2 \\
\hline 5 & & Propriety & 5 & & 1 & & 1 & 1 & 1 & & & & & & 9 \\
\hline 6 & Negative & Normality & 32 & & & & 1 & 1 & & & 2 & 2 & & & 38 \\
\hline 7 & & Capacity & 2 & & & & & & & & & & & & 2 \\
\hline 8 & & Tenacity & 1 & & & & & & & & & & & & 1 \\
\hline 9 & & Veracity & 6 & & & & 1 & & & & 1 & & & & 8 \\
\hline 10 & & Propriety & 55 & 1 & 4 & & & & 1 & & 2 & 2 & 1 & 1 & 67 \\
\hline \multicolumn{3}{|c|}{ Total } & 151 & 1 & 10 & 1 & 5 & 5 & 2 & 1 & 9 & 7 & & 1 & 194 \\
\hline
\end{tabular}

Description: Established Equivalent (EE), Reduction (Re), Transposition (Tr), Discursive Creation (DC), Implication (Im), Modulation (Mo), Explicitation (Ex), Deletion (Del), Paraphrase (Pa).

Table 2 presents eight translation techniques used, including couplet techniques in translation words, phrases, and clauses containing judgment expressions. The techniques used include Established Equivalent, Reduction, Transposition, Discursive Creation, Implication, Modulation, Explicitation, Deletion, and Paraphrasing. 
The FGD found that the most frequently used technique in translating the Judgment expression in this TV series is Established Equivalent. Established Equivalent is a translation technique that uses terms or expressions that are already common or matching used by TL readers (based on dictionaries and everyday usage). For example:

Data 97/ ep 25/ minute 25:28

ST : 你这般破坏规矩 [Ň̌ zhè bān pòhuài guījǔn]

TT : Kau melanggar peraturan

Data 95 above indicates that both ST and TT are Judgment expressions in the form of Capacity (-). Capacity is the ability of a person who is at the level of social esteem. From the sentence above, the word 破坏 is 【pòhuài】 has the meaning of damaging or merusak while 规矩 [guījǔ] has the meaning of rule or aturan. The speaker in this sentence is one of the main character's classmates, where he comments that Wei Wuxian has broken the rules for the umpteenth time. They said that he still had the ability to damage or in the context of this sentence was a violation or melanggar of the rules set by the Lan Clan. Thus, the term “破坏规矩” when translated using PL has the same meaning as ST, namely negatively charged Capacity. The second most frequently used technique is discursive creation. This technique uses equivalents that come out of the SL context which usually aims to attract the interest of TL readers.

Data 3/ ep 1/ minute 5:28

ST : 何等风光恣意 [Héděng fēngguāng zìyì]

TT : Betapa mulia

The third data above shows a phase of 何等风光恣意, which comes from 年少成名, 何等风光 恣意[Niánshào chéngmíng, héděng fēngguāng zìyì]. This phrase describes the ability or strength of the main character. The context in this expression explains how great the main character is because since he was young he has been known by everyone because of his prowess. The translator used the DC technique to translate the phrase “何等风光恣意” into how glorious or "betapa mulia". The use of this technique causes a change in the Judgment type, where the Judgment type ST pad is Capacity (+) but changes into Normality (-) after being translated.

The third technique used is the modulation technique of 5 data. One example is presented in the data below:

Data 175/ ep 42/ minute 16:49

ST ：他处心积虑骗了我们所有人 [Tā chǔxīnjīlù piànle wǒmen suǒyǒu rén]

TT : Dia menipu kita semua.

Data 175 is Veracity (-) (type of Judgment which discusses the level of honesty of a person) which is at the level of Social Sanction with Graduation metaphor which is translated using modulation technique. The phrase 处心积虑 [chǔxīnjīlù], a Chinese metaphor, which means to justify any means to achieve something evil, is translated into the word deceiving or menipu. The use of this technique changes the type of Graduation from metaphor to attitudinal lexis which causes a shift in translation that affects the quality of the translation.

The fourth technique used with a total of 4 data is explicitation.

Data $173 /$ ep 40/ minute 12:19

ST: 脸皮可真够厚的 [Liănpí kě zhēn gòu hòu de]

TT : Dia tidak tahu malu

The Impact of Translation Techniques on the Quality of Translation of Judgment Expression that Describes the Main Characters in the Untamed TV 265
Series 
Data 173 show a metaphor that is translated into Indonesian in the form of a clause using an explicitation technique. 脸皮可真够厚的 [Liănpí kě zhēn gòu hòu de] literally means his face is really thick or wajahnya benar-bener tebal in Indonesian. The word 脸皮 [Liănpí] in the phrase describes shame. Thus, the phrase is translated explicitly to shameless or tidak tahu malu. The use of this technique causes a shift in the type of Graduation from metaphor to polarity.

The fifth technique used is the transposition technique. Examples can be seen in the following data.

Data 138/ ep 30/ minute 34:26

ST : 魏无美杀人如麻 [shārén rú má]

TT : pembunuh kejam

The data 138 above shows that the phrase 杀人如麻 [Shārén rú má] is a metaphor which literally means killing people like killing straw or membunuh orang seperti membunuh jerami in Indonesian. The meaning of this metaphor/idiom is that it is very easy for him to kill someone. The use of transposition technique was found where the word 杀 [shā] which means to kill or membunuh is translated into murderer or pembunuh. There is a change in the type of graduation from metaphor (raised) to attitudinal lexis (raised) but it does not affect the quality of the translation.

Besides using one technique, there are where the translator combines 2 techniques (couplet technique) to translate judgment expressions. As described in the table above, the highest use of the couplet technique is the reduction and established equivalent 9 times, established equivalent and discursive creation 7 times, reduction and transposition at least 1 time, and explicitation and discursive creation at least 1 time. Examples of the use of couplet techniques were as follows:

Data 9/ ep 3/ minute 4:51

ST : 谁思你了? 真不要脸 [Shéi sī nǐle? Zhēn bùyào liăn]

TT : Siapa yang merindukanmu? Dasar tak tahu malu

Data 19 is categorized into a type of Judgment Propriety (-) which is translated using reduction technique and established equivalent technique. The word 脸 [liăn] from clause 真不要脸 [Zhēn bùyào liăn] is translated using the meaning appropriate to the context of the situation (the speaker questions Wei Wuxian's shameless behavior to tease him even though they do not know each other). The reduction technique is also used to remove the word 真 [zhēn] from clause 真不要脸 [Zhēn bùyào liăn] which literally means completely. The omission of the word 真 [zhēn] in the TT resulted in a change in the type of Graduation from Intensifier (raised) to attitudinal lexis (raised), thus becoming shameless or tidak tahu malu. The use of these two techniques results in a shift in terms of graduation which causes a shift in the meaning of the translation.

Data 13 / ep 3/ minute 20:37

ST : 私带就入内 $[\mathrm{Sī}$ dài jiù rùnèi $]$

TT : Membawa miras tanpa izin

Data 13 is a judgment expression that combines two techniques, namely the explicitation technique and the established equivalent. The word 私 [ $\left.\mathrm{S}_{1}\right]$ which means personal or pribadi indicates that the clause 私带入内 means to bring personal belongings in. the translation of the word 私 is made explicit to be alcohol because in the previous dialogue it was told that the main character intentionally brought liquor into the Gusu Lan environment (the name of the place where they studied) which is forbidden. The word 入内 is also made explicit to be tanpa izin or without permission, because bringing in or membawa masuk (入 内) has the same meaning as smuggling or bringing in without permission. The PL technique is used to 
translate the word带 to membawa or bring. The use of these techniques does not change the type of Judgment, both ST, and TT in the form of Propriety (-).

The next use of couplet technique is reduction and transposition which is seen in the following example:

Data 47/ ep 8/ minute 13:41

ST : 你很器张啊 [Nǐ hěn xiāozhāng a]

TT : Dasar pria arogan

Data 47 is one of the Judgment expressions of normality (-). A phrase 很器张, the ST shows reduction and transposition techniques used into arogan or arrogant. The word 很 which means very reduced make that from ST could be translated from very arrogant (sangat arogan) to arrogant (arogan), resulting in the type of graduation from intensifier (high raised) to attitudinal lexis (raised). It shows a shift in translation that affects the quality of the translation.

\subsection{Quality of Translation of Judgment Expressions}

The use of the translation technique in translating the Judgment expression can affect the results of the quality of the translation. Nababan et al (2012) explain the quality of translation can be seen from the accuracy, acceptability, and readability. Of the three points, the most important is maintaining the accuracy of the translation results, followed by acceptance of the target text, and the last is readability. The results of the translation quality of this TV series are presented in Table 3.3.

Table 3.3 Accuracy, Acceptability, and Readability of Judgment Expressions

\begin{tabular}{|c|c|c|c|c|c|c|c|c|c|c|c|c|}
\hline \multirow{3}{*}{ No } & \multirow{3}{*}{\multicolumn{2}{|c|}{ Type of Judgment }} & \multirow{4}{*}{$\begin{array}{c}\text { Transalation } \\
\text { Techniques } \\
\text { EE } \\
\end{array}$} & \multicolumn{9}{|c|}{ Translation Quality } \\
\hline & & & & \multicolumn{3}{|c|}{ Accuracy } & \multicolumn{3}{|c|}{ Acceptability } & \multicolumn{3}{|c|}{ Readibility } \\
\hline & & & & $\mathbf{3}$ & 2 & 1 & $\mathbf{3}$ & 2 & 1 & 3 & 2 & $\mathbf{1}$ \\
\hline \multirow{6}{*}{$\mathbf{1}$} & \multirow{21}{*}{ Positive } & \multirow{6}{*}{ Normality } & & 23 & - & - & 23 & - & - & 23 & - & - \\
\hline & & & DC & - & - & 1 & 1 & - & - & 1 & - & - \\
\hline & & & $\mathrm{Im}$ & 1 & - & - & 1 & - & - & 1 & - & - \\
\hline & & & $\mathrm{Re}+\mathrm{Tr}$ & - & 1 & - & 1 & - & - & 1 & - & - \\
\hline & & & Re+EE & - & 2 & - & 2 & - & - & 2 & - & - \\
\hline & & & $E E+D C$ & - & 1 & - & 1 & 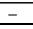 & - & 1 & - & - \\
\hline \multirow{5}{*}{$\mathbf{z}$} & & \multirow{5}{*}{ Capacity } & EE & 15 & - & - & 15 & 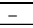 & - & 15 & - & - \\
\hline & & & DC & 1 & - & 2 & 3 & - & - & 3 & - & - \\
\hline & & & Mod & - & 1 & - & 1 & $\begin{array}{lll}- \\
\end{array}$ & - & 1 & $\begin{array}{llll}- & & & 0\end{array}$ & - \\
\hline & & & $R e+E E$ & - & 1 & - & 1 & $\begin{array}{lll}- & & 0\end{array}$ & - & 1 & - & \\
\hline & & & $E E+D C$ & - & 2 & - & 2 & $\begin{array}{llll}- & & & 0\end{array}$ & - & 2 & 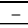 & $\begin{array}{cc}- \\
-\end{array}$ \\
\hline \multirow{3}{*}{$\mathbf{3}$} & & \multirow{3}{*}{ Tenacity } & EE & 12 & - & - & 12 & - & - & 12 & 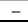 & - \\
\hline & & & DC & - & 1 & - & 1 & - & 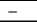 & 1 & 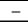 & - \\
\hline & & & Ex & 3 & - & $\begin{array}{ll}- \\
-\end{array}$ & 3 & $\begin{array}{llll}- & & & \end{array}$ & $\begin{array}{ll}- \\
\end{array}$ & 3 & $\begin{array}{cc}- \\
-\end{array}$ & - \\
\hline \multirow{2}{*}{4} & & \multirow{2}{*}{ Veracity } & EE & 1 & - & - & 1 & - & - & 1 & - & - \\
\hline & & & Mod & 1 & - & - & 1 & $\begin{array}{llll}- & & & \end{array}$ & - & 1 & $\begin{array}{c}- \\
-\end{array}$ & - \\
\hline \multirow{5}{*}{5} & & \multirow{5}{*}{ Propriety } & EE & 5 & - & $\begin{array}{ll}- \\
-\end{array}$ & 5 & $\begin{array}{llll}- & & & 1\end{array}$ & $\begin{array}{ll}- \\
\end{array}$ & 5 & 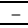 & $\begin{array}{cc}- & \\
\end{array}$ \\
\hline & & & $D C$ & $\begin{array}{cc}- & \\
\end{array}$ & 1 & - & 1 & - & - & 1 & 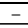 & - \\
\hline & & & Mod & 1 & - & - & 1 & $\begin{array}{llll}- & & & 0\end{array}$ & - & 1 & - & 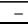 \\
\hline & & & Ex & 1 & - & - & 1 & $\begin{array}{lll}- \\
\end{array}$ & - & 1 & - & - \\
\hline & & & Del & - & - & 1 & - & $\begin{array}{llll}- & & & 0\end{array}$ & 1 & - & - & 1 \\
\hline \multirow{5}{*}{6} & \multirow{18}{*}{ Negative } & \multirow{5}{*}{ Normality } & EE & 32 & - & - & 32 & $\begin{array}{lll}- & & \\
\end{array}$ & $\begin{array}{ll}- & \\
\end{array}$ & 32 & 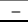 & - \\
\hline & & & Mod & $\begin{array}{llll}- & & & \end{array}$ & 1 & - & 1 & $\begin{array}{llll}- & & & \end{array}$ & - & 1 & $\begin{array}{c}- \\
-\end{array}$ & - \\
\hline & & & Ex & 1 & - & - & 1 & - & - & 1 & 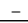 & - \\
\hline & & & Re+EE & 1 & 2 & - & 3 & - & - & 3 & - & - \\
\hline & & & $E E+D C$ & - & 1 & $\begin{array}{ll}- \\
-\end{array}$ & 1 & $\begin{array}{llll}- & & & \end{array}$ & $\begin{array}{ll}- & \\
\end{array}$ & 1 & 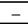 & $\begin{array}{cc}- & \\
\end{array}$ \\
\hline 7 & & Capacity & EE & 2 & - & - & 2 & $\begin{array}{llll}- & & & 0\end{array}$ & $\begin{array}{ll}- \\
\end{array}$ & 2 & 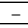 & 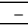 \\
\hline 8 & & Tenacity & EE & 1 & - & - & 1 & - & - & 1 & - & - \\
\hline & & & EE & 6 & - & - & 6 & $\begin{array}{llll}- & & & 0\end{array}$ & - & 6 & - & - \\
\hline 9 & & Veracity & Mod & - & 1 & $\begin{array}{l}- \\
-\end{array}$ & 1 & $\begin{array}{llll}- & & & \\
\end{array}$ & $\begin{array}{lll}- & & \end{array}$ & 1 & 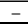 & - \\
\hline & & & Re+EE & - & 1 & - & 1 & - & - & 1 & - & - \\
\hline & & & EE & 55 & - & - & 55 & - & $\begin{array}{llll}- & & & \\
\end{array}$ & 55 & $\begin{array}{cc}- \\
\end{array}$ & - \\
\hline & & & Tr & 1 & - & $\begin{array}{ll}- \\
-\end{array}$ & 1 & $\begin{array}{lll}- & & \end{array}$ & - & 1 & - & - \\
\hline & & & $D C$ & 1 & 1 & 2 & 4 & - & - & 4 & - & - \\
\hline 10 & & Propriety & Del & - & - & 1 & $\begin{array}{ll}- \\
-\end{array}$ & $\begin{array}{lll}- & & \end{array}$ & 1 & - & $\begin{array}{cc}- & \\
\end{array}$ & 1 \\
\hline 10 & & Propriety & Re+EE & - & 2 & 1 & 3 & $\begin{array}{ll}- \\
-\end{array}$ & $\begin{array}{llll}- & & & 0\end{array}$ & 3 & 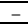 & $\begin{array}{cc}- & \\
\end{array}$ \\
\hline & & & $E E+D C$ & - & 1 & - & 1 & - & $\begin{array}{llll}- & & & \\
\end{array}$ & 1 & $\begin{array}{lll}- \\
\end{array}$ & - \\
\hline & & & $E x+E E$ & 1 & - & - & 1 & - & - & 1 & - & - \\
\hline & & & $\mathrm{Pa}$ & 1 & - & - & 1 & $\begin{array}{llll}- & & & 0\end{array}$ & - & 1 & $\begin{array}{cc}- \\
\end{array}$ & - \\
\hline & & & TOTAL & 166 & 20 & 8 & 192 & & 2 & 192 & & 2 \\
\hline
\end{tabular}

The table above presents that the use of an established equivalent technique does not affect the quality of the translation. Meanwhile, the use of the couplet technique, modulation technique, and discursive creation technique cause the translation accuracy to decrease as evidenced by the presence of 20 data that gets a score of 2. Meanwhile, the use of deletion in some causes inaccuracies in the translation results of Judgment expressions. As for the acceptability and readability of the translation of Judgment, 
expressions can be said as acceptable and has high legibility. There are only two data that get a score of 1 because it is due to the use of the deletion technique.

The decrease in the translation quality of Judgment expressions in this study was due to an Appraisal shift caused by the use of inappropriate techniques. The table below presents more clearly the types of shifts that occur.

Table 3.3.1 Impact of Shifts on Translation Quality

\begin{tabular}{|c|c|c|c|c|c|c|c|}
\hline \multirow{2}{*}{ No Data } & \multirow{2}{*}{$\begin{array}{c}\text { Type of } \\
\text { Judgment }\end{array}$} & \multicolumn{2}{|c|}{ Translation Shift } & \multirow{2}{*}{ Techniques } & \multirow{2}{*}{ KA } & \multirow{2}{*}{ KB } & \multirow{2}{*}{ KT } \\
\hline & & ST & $T T$ & & & & \\
\hline 1 & capacity + & intensifier (raised) & att lexis (raised) & $\mathrm{PL}$ & 2 & 3 & 3 \\
\hline 3 & capacity + & capacity + & normality + & $\mathrm{DC}$ & 1 & 3 & 3 \\
\hline 4 & propriety - & Appraisal & Not Appraisal & Del & 1 & 1 & 1 \\
\hline 9 & propriety - & intensifier (high raised) & att lexis (raised) & $\mathrm{Re}+\mathrm{PL}$ & 2 & 3 & 3 \\
\hline 17 & capacity + & methapor (high raised) & att lexis (raise) & Red+EE & 2 & 3 & 3 \\
\hline 20 & capacity + & att lexis (raised) & att lexis (high raised) & $\mathrm{EE}+\mathrm{DC}$ & 2 & 3 & 3 \\
\hline 21 & capacity + & att lexis (raised) & att lexis (high raised) & $\mathrm{EE}+\mathrm{DC}$ & 2 & 3 & 3 \\
\hline 27 & propriety - & propriety - & normality - & $\mathrm{EE}+\mathrm{DC}$ & 2 & 3 & 3 \\
\hline 30 & propriety + & propriety + & not translated & Del & 1 & 1 & 1 \\
\hline 33 & veracity - & intensifier (high raised) & polarity (raised) & Red+EE & 2 & 3 & 3 \\
\hline 39 & propriety - & propriety + & tenacity - & DC & 1 & 3 & 3 \\
\hline 41 & proprietyn + & propriety+ & tenacity - & DC & 2 & 3 & 3 \\
\hline 45 & propriety - & propriety - & normality + & DC & 1 & 3 & 3 \\
\hline \multirow{2}{*}{46} & \multirow{2}{*}{ normality +} & mental process & attribute & \multirow{2}{*}{ Red+Tr } & \multirow{2}{*}{2} & \multirow{2}{*}{3} & \multirow{2}{*}{3} \\
\hline & & intensifier (high raised) & implied raised & & & & \\
\hline 47 & normality - & intensifier (high raised) & att lexis (raised) & Red+EE & 2 & 3 & 3 \\
\hline 50 & normality - & att lexis (raised) & intensifier (raised) & $\mathrm{PL}$ & 3 & 3 & 3 \\
\hline 53 & capacity + & att lexis (raised) & intensifier & Mod & 2 & 3 & 3 \\
\hline 54 & tenacity + & attibute & proses material & $\mathrm{DC}$ & 2 & 3 & 3 \\
\hline 62 & propriety - & implied (raised) & att lexis (raised) & DC & 2 & 3 & 3 \\
\hline 66 & propriety + & metaphor (raised) & implied (raised) & Ex & 3 & 3 & 3 \\
\hline 78 & normality - & downtoner lowered raise & downtoner medium (raised) & Red+EE & 3 & 3 & 3 \\
\hline 81 & propriety - & intensifier (high raised) & implied (raised) & Red+EE & 2 & 3 & 3 \\
\hline 82 & capacity + & capacity + & propriety + & DC & 1 & 3 & 3 \\
\hline 93 & normality - & att lex (raised) & intensifier (high raised) & $\mathrm{EE}+\mathrm{DC}$ & 2 & 3 & 3 \\
\hline \multirow{2}{*}{118} & \multirow{2}{*}{ normality +} & normality + & capacity+ & \multirow{2}{*}{ DC } & \multirow{2}{*}{1} & \multirow{2}{*}{3} & \multirow{2}{*}{3} \\
\hline & & att lexis (raised) & implied (raised) & & & & \\
\hline 120 & normality + & att lexis (raised) & metafor (raised) & $\mathrm{Im}$ & 3 & 3 & 3 \\
\hline 121 & normality + & metafor (raised) & att lexis (raised) & $\mathrm{PL}$ & 3 & 3 & 3 \\
\hline 133 & capacity + & metafor(raised) & implied (raised) & $\mathrm{EE}$ & 3 & 3 & 3 \\
\hline 135 & normality + & intensifier (raised) & att lexis (raised) & Red+EE & 2 & 3 & 3 \\
\hline 136 & normality + & intensifier (raised) & att lexis (raised) & Red+EE & 2 & 3 & 3 \\
\hline 138 & propriety - & metafor (raised) & att lexis (raised) & $\mathrm{Tr}$ & 3 & 3 & 3 \\
\hline 139 & propriety - & metafor(raised) & att lexis (raised) & $\mathrm{EE}$ & 3 & 3 & 3 \\
\hline 140 & propriety - & intensifier (raised) & att lexis (raised) & Red+EE & 2 & 3 & 3 \\
\hline 146 & normality - & metafor & sharpening & Mod & 2 & 3 & 3 \\
\hline 157 & normality - & intensifier (high raised) & att lexis (raised) & $\mathrm{Re}+\mathrm{EE}$ & 2 & 3 & 3 \\
\hline 173 & normality - & metafor (raised) & polarity (raised) & Ex & 3 & 3 & 3 \\
\hline 175 & veracity - & metafor (raised) & att lexis (raised) & Mod & 2 & 3 & 3 \\
\hline 177 & prorpiety + & metafor (raised) & att lexis(raised) & $\mathrm{EE}$ & 3 & 3 & 3 \\
\hline 190 & normality - & att lexis(raised) & intensifier (raised) & $\mathrm{EE}+\mathrm{DC}$ & 2 & 3 & 3 \\
\hline 191 & normality + & att lexis (raised) & sharpening & $\mathrm{EE}+\mathrm{DC}$ & 2 & 3 & 3 \\
\hline
\end{tabular}

There are 41 data from 194 data which after being translated into Indonesian experienced a shift. A shift in some of the data will affect the quality of the translation. However, some data experience a shift in the type of judgment but do not affect the quality of the translation results at all. More details can be seen in the example below:

\section{Data 4/ ep 2/ minute 18: 36}

ST : 这江厌离也是冤, 带出这个白眼狼 [Zhè jiāng yàn lí yěshì yuān, dài chū zhège báiyăn láng]

TT : Wanita yang sungguh sial! Dia mempercayai Wei dan dibunuh.

The sentence 带出这个白眼狼 [dài chū zhège báiyăn láng] literally means carrying this white-eyed wolf or membawa serigala bermata putih ini. The word 白眼狼 [báiyăn láng] is an idiom which means that The Impact of Translation Techniques on the Quality of Translation of Judgment Expression that Describes the Main Characters in the Untamed TV 268 Series 
after being helped, instead of thanking the person, it harms the person who helped. 白眼狼 [báiyăn láng] is a Judgment expression used by one of the characters to describe the main character. However, when translated into Indonesian, the word is omitted (deletion technique). Thus, the sentence in the TT, which was previously an expression of Judgment, becomes not a judgment for it does not accurately describe what the speaker wants to convey in the TV series. The use of this technique also affects the acceptability and tolerability of TT.

Data 45/ ep 7/ minute 39:07

ST : 蓝忘机那么讨厌你, 你干吗老去招惹人家 [Lán wàng jī nàme tăoyàn nǔ, nǐ gànma lăo qù zhāorě rénjiā]

TT : Lan Wang Ji sangat membecimu, kenapa kau akrab dengannya?

Data 45 shows a shift in the Judgment type caused by the use of discursive creation technique from Propriety (-) to Normality (+). The word 招惹 [zhāorě] which means disturbing or teasing (mengganggu or menggoda) turns into familiar or akrab. It can be seen that in ST, the speaker evaluates the politeness value of the main character which is negative (propriety -), but when translated using discursive creation technique, it turns out to evaluate the behavior of the main character to be positive (normality + ). This causes the accuracy of Judgment's expression to be inaccurate.

Data 118 /ep 28/ minute 6:34

ST : 在四大家族面前,你是怪杰 [Zài sì dà jiāzú miànqián, nǐ shì guài jié,

TT : Di mata empat klan utama, kau adalah kutu buku

The word 怪杰 [guài jié] in data 118 has the meaning of talented person or orang yang berbakat. However, when translated into Indonesian, it becomes a geek or kutu buku. A discursive creation technique is used, but it produces a translation meaning that is much different from the original text. Apart from the inaccurate meaning, the type of judgment also experienced a shift, from normality + to capacity + . It also shifted to the type from attitudinal lexis (raised) to implied (raised).

Data 53/ ep 11/ minute 32:31

ST : 好！师兄果然厉害 [Hăo! Shīxiōng guǒrán lihài]

TT : Bagus! Sudah pasti Tuan Muda Wei yang terbaik.

Data 53 shows a shift due to the use of the couplet technique which slightly affects the accuracy of the translation. The word 厉害 [lìhài] means great or hebat when translated into Indonesian. It is categorized into Capacity (-) with the type of graduation attitudinal lexis. However, when translated into the best or terbaik, there is a shift in the type of Graduation to intensifier (raised). The word terbaik or the best has a superior meaning or sangat where ST does not mention any word which indicates sangat (In Chinese sangat is translated as 真).

Besides the above example which shows a shift in Appraisal that causes a decrease in the quality of the translation, another shows a Judgment shift that does not affect the quality of the translation at all.

Data 66/ ep 19/ minute 13:00

ST : 魏公子当日在玄武洞中英雄救美 [Wèi gōngzǐ dāngrì zài xuánwǔdòng zhōng yīngxióng jiù měi]

TT : menjadi pahlawan dan menyelamatkan gadis dalam masalah. 
In data 66, the phrase 英雄救美 [yīngxióng jiù měi] is propriety (-) with the type of graduation of metaphor (raised). The phrase when translated into Indonesian literally means a hero saves a beautiful girl. By using the technique of explicitation, the phrase is translated into menjadi pahlawan dan menyelamatkan gadis dalam masalah (being a hero and saving the girl in trouble). It can be seen that the expression of judgment when translated the type of graduation turns into implied (raised). Although the type of graduation shifted, the meaning conveyed ST to TT did not change. Thus, the accuracy, acceptability, and readability of the translation obtain a high score.

\section{Conclusion}

There are 194 Judgment expression data found in The Untamed TV Series. Judgment types found in this TV series include normality, capacity, tenacity, veracity, and propriety. The selection of an inappropriate technique in translating the Judgment expression can not only change the type of Judgment but also cause a change (shift) in the type of Graduation. This might cause changes in meaning that affect the quality of the translation.

In order to maintain the quality of the translation, an understanding of other branches of knowledge besides translation can help in determining the use of techniques. As in this study, a translation approach used was Appraisal. Appraisal clearly presents that during the translation process, the translator not only needs to concern with the meaning of the ST and SL, but also the function of the text or expression the character has, how the character describes, and what causes the character to express the expression since Appraisal examines meaning in interpersonal which is following the principles of a good translation, which is to produce a holistic translation.

\section{References}

Aji, W., Nababan, M.R., \& Santosa R. (2017). Comparative translation quality of judgment in novel the adventure of tom sawyer. Lingua Didaktika. 11(1), 36-52. doi:10.24036/Id.v11i1.7709

Iswandi, F. (2019). Kajian terjemahan kata, frasa dan klausa yang mengakomodasi attitude pada tokoh utama dalam novel Animal Farm karya george orwell dan dua versi terjemahannya (bakdi dan mahbub) (kajian terjemahan dengan pendekata appraisal). Tesis: Universitas Sebelas Maret

Martin, J.R., \& Rose, D. (2007). Working with discourse (2 Ed). London/New York: Continuum

Martin, J.R., \& White, P. R. P. (2005). The language of evaluation. New York: Palgrave Macmillan

Molina, L., Albir, A. H. (2002). Translation techniques revisited: A dynamic and functionalist approach. Meta: Translator's Journal, 47(4), 498-512. https://doi.org/10.7202/008033ar

Nababan, M.R., Nuraeni, \& Sumardiaono. (2012). Pengembanagan model penilaian kualitas terjemahan. Kajian Linguistik Dan Sastra, 24(1),39-57

Santosa, R. (2017). Metode penelitian kualitatif kebahasaan. Surakarta:UNS Press

Sutrisno, A. (2017). Analisis ungkapan-ungkapan sikap tokoh utama dalam novel The Body in The Library karya agatha christie dan pengaruhnya terhadap kualitas terjemahan (kajian terjemahan dengan pendekatan teori appraisal). Tesis: Universitas Sebelas Maret

Zhouying, H. (2017). Analisis terjemahan subtitle bahasa Indonesia mengenai tokoh utama dalam film The Monkey King (2014) dari perspektif appraisal. Tesis: Universitas Sebelas Maret.

\section{Copyrights}

Copyright for this article is retained by the author(s), with first publication rights granted to the journal.

This is an open-access article distributed under the terms and conditions of the Creative Commons Attribution license (http://creativecommons.org/licenses/by/4.0/). 